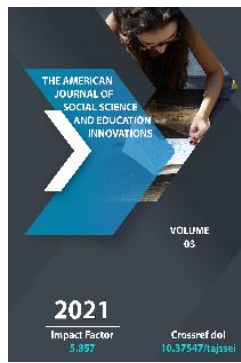

\title{
Socioeconomic Factors Of UAL Migration In The Educational System
}

\author{
Fatxulla Abduvaliyev \\ National University Of Uzbekistan, Researcher Of The Department Sociology, Uzbekistan
}

Journal Website:

https://theamericanjou

rnals.com/index.php/ta

jssei

Copyright: Original content from this work may be used under the terms of the creative commons attributes 4.0 licence.

\section{ABSTRACT}

It is worth noting that today's intellektual migration has become an integral part of the World Economic Relations. The more serious impact international labour migration has on the level of development and the indicators of statistical data around the world, intellektual migration has made its social and economic appearance completely unique. While labor migration has affected ethnic and religious factors, ual migration has linked professional activity to talent and ability. As the process of migration is studied by the state migration centers, the regulation of the migration policy is used by various bureaucratic bodies to slow down its possibilities, but this can stop the ongoing processes only for a certain period of time, which can not be the main task of getting out of the problem, since bureaucratic measures adversely affect.

\section{KEYWORDS}

Technological forever, bureaucratic, socio-economic processes, organization of effective management, cultural-political, moral and spiritual discharge.

\section{INTRODUCTION}

As with any technological forever, bureaucratic activity has its own culminability, that is, it has its own final point, and when it climbs to its peak and bureaucratic activities go out in full swing, when its final point is realized, a very large number of talented and highly professional people who are waiting for the situation can leave the country. And this leads not only to socio-economic processes, but also to cultural-political, moral and spiritual discharge.When assessing the object of migration legislation and its social 
consequences, in the organization of effective management, attention is paid to the positive approach, the essence of this approach is based on the results of individual selection, the nature of which depends on a number of factors: the behavior of each individual or family migratory, the geographical, economic and environmental aspects of these factors

It is aimed at the study of migration processes and is written in the spirit of historiography. The work of Thomas, F Znanesky, consisting of five volumes, titled "Polish peasant in Europe and America" methodologically has not lost its relevance to this day. Based on the theory, this work explores aspects that have shaped new patterns of migrant behavior, the authors conclude: "migrant behavior is adaptation to this environment and of course the nervous system.it will continue in forms of adaptation." The perfection of the work is that both authors were sociological leaders in their time problems, revealed them with the help of scientific research, until now the work has not lost its elite significance.

Based on the study of the personal documents of the emigrant, the information obtained and the typology of the new social character during the conversations with them is developed on the example of individual people. Sociological analysis of adaptation, adaptation of an individual to the environment, in what order it takes place. In the doctrine of subsequently served to establish the instrument of effective social policy in the designation of the migrant social character. The role of the theory of "Human Ecology", which took an important place in American sociology in the 60-70-ies of the XX century in the study of Migrant social behavior, was great, but then the prestige of this theory fell and lost its significance. R.Park and R.This doctrine, founded by the McKenzies, was formed under the influence of industrialization and human social behavior of urbanization.

\section{MATERIALS AND METHODS}

The reasons for this incomprehensible theory for many specialists and sociologists are explained by the following indications: first, since the character of migration and migrant is located in a particular environment and here it is through reproduction (population), then it is not necessary to indicate the process of adaptation (adaptation). Secondly, some researchers compare adaptation to the "black box". According to him, those who are on the move and those who are affected by it are not visible. Thirdly, the main goal of criticizing human ecology is four subjects, namely a) reproduction (population). b) organization, C) external environment, d) technology is not interconnected . In sociology, the methodology in the criticism of migration or intellektual migration is a structural functional theory. The social factor of migrants is regarded as a result of systematic fuctional one (T.Parsans). The participation of the population in the migration process is a longterm social transformation, the participation of the people's community in various forms of migration, calling it a dysfunctional state, that is, fear in people pressure painful points are observed (E.Dyurkgeym). Also, the social function of a migrant can be divided into specific and delayed (latent) classifications (R.Merton). By the 70-ies of the XX century, M.Kastels, M.Nikolinakos, G.Kosak and S.In the works of Castle, the processes of migration are covered based on the theory of dependence on development, aimed at the uneven development of capitalism and the nonexistence of the world system in one plane. In their teachings, migrant workers, including intellektual migrants, are also known as"reserve labor troops "and they are regarded as a force" raising the standard of living of Western countries " in their embodiment, and in order to attract any physical activity, heavy or light work, Western countries are primarily recruited from outside such labor forces, 
among immigrants or participants in the migration process.

The former external colonies are replaced by a new one, only now they are called internal colonies. On a global scale, the capitalist system retreats from remote areas, centralizes, and the capital fund is viewed upon by demographic processes. As Emigrant countries remain the previous colonies itself, now the source of social fallout is carried out on the account of the emigrant.

M.In the theory of assimilation or mixing of Gordin and handlines, the adaptation of an emigrant to another country is carried out on the basis of a linear principle of the process, the theory of mixing is a random phenomenon, in which a small number of foreign migrants are used and this is focused on it as a general functional paradigm of sociology.

From modern researchers g.Jeron and y.The teaching of the lion (Pull/Push) attraction displacement) is of great interest, according to this teaching, it is understood that the place where people live should be replaced or moved to other urban areas and countries where the necessary conditions are created. Geographically (Pull and push) factors are those that pull people away from something and pull them to a new place. (Pull and Push) a combination of factors helps to identify immigration of the population in migration processes or separately from one place to another (Pulland Push) theory is one of the most important theories for the study of migrant populations and migrants from one place to another. The theory preserves that the causes of migration and immigration can improve their living conditions through migration of people.

Bunda differs by three main groups. The first is

a) To go to the place of attraction. b) Cutting

c) The direction of the migrant according to which the factors that cause the process to take place in the migrant producing countries, that is, the way the cutting is chosen and the scheme of Attraction works . Ual migration is a theory that focuses on the study of migration problems and their quantity and composition, personal description and psyche, taught through ethnosociological teaching its manifestations K.Davis, Yo.Arutyunian, L.While studies migrants as a social group, they focus on the goals for which individual wishes are received. Ethnosociological direction focuses on the processes of transformation of historical traditions, depending on the factor of culture and the social environment. The historical approach of Bunda brings the ethnosiological approach into the body in harmony with the ethnographic approach.

The theory of social activity is reflected in Max Webernint's understanding sociology and focuses on the research of models of social self-activity in the determination of the position of migrants. Also T.The structural structure of the Parsons is A.Tshots, P.Birger, T. The phenomenological teaching of the lukmans and g.In Garfinkel's etn methodology, the interpretation of social reality is studied by linking it to migration processes.

The theory of migration-related or the theory of migration relations in Western sociology has been widely interpreted in recent years, in which it is called g.Louri's social capital doctrine applies. In this teaching P.Burd'e also supports. The theory of Social Capital Network hypotheses interprets the bug of migrant life and the interconnectedness of the past. The Migration Network, it says, analyzes the lack of cooperation or disagreement, sympathy or antipathy, friendship or mutual understanding between migrants and local residents as a result of their interaction with each other. In 
general, Network Relations change the life of a migrant towards positivity in this or that aspected, another doctrine that considers migration processes as an attribute of social reality is the theory of social change, the founders of this doctrine are Y.Shepansky, P.Staples promote the act of mutual activity of migrants in the interpretation and research of social functions.

In general, the sociological study of migration, migration, is of scientific importance, it is classified in the following directions:

- Migration mobility occurs between different social groups of the population (ual migration also);

- The territorial location of the migrant (ual migrant) or the designation of a place of his / her own, based on his / her social status;

- Circumstances affecting migration mobility may include social origin, education, social status and Ethnos-confessional aspects;

- The impact of social and referent groups that determine migrant behavior on the current or past environment, the impact of the dynamics of personal guidelines on migrant consciousness and behavior;

- The interests and expectations of the individual and social groups in the process of changing the place of residence and adapting to the new one;

- Special legislation on the movement of migration processes;

- General and specific recommendations for migrant behavior, the social mechanism of their regulation;

- Social and ethnosocial cooperation of migrants (integration) and adaptation to conditions (adaptation). bunda will focus on studying the language of another place, mastering the laws and regulations, marriage in the immigrant environment, self-awareness and assessment as a migrant;

- The political activity of a migrant and his political role in a new society, issues of nationalism or chauvinism, as well as cultural contradictions that can be expected.

It is necessary to establish associations of the Republic or local state structures, nongovernmental organizations, educational institutions, professional communities, organizations interested in the implementation of the proposed measures, create conditions for the operation of these ideas and eliminate the problems that will arise soon.

\section{REFERENCES}

1. Todaro $M$. Internal migration in developing countries: a survey // Population and economic change in developing countries. / Ed. R. Easterlin. - Chicago: University of Chicago Press. - 1980. - P.361-402.

2. Thomas W., Znaniecki F. The Polish peasant in Europe and America. - New York, 1958.C.741.

3. Park R. Human ecology// The theory of society. / Edited by A. F. Filippov. - M.: Canon-Press-Ts, Kuchkovo field, 1999. pp. 384-401.

4. https://www.thoughtco.com/pushpull-factors-1434837

5. Nemeryuk E. E. Migration as a type of social mobility in modern Russian society (theoretical and methodological aspect). Abstract of the dissertation for the degree of Candidate of sociological Sciences. Saratov, 2000.

6. Iontsev V. A. Sociological approaches to the study of population migration. $264-374$.

7. A NEW STAGE OF REFORMING THE TRAINING OF LEGAL PERSONNEL. F Mukhitdinova Review of law sciences 2 (1), 2017.

8. Ideas and teachings for the concept of spiritual and moral education of the 
The American Journal of Social Science and Education Innovations (ISSN - 2689-100x)

Published: August 31, 2021 | Pages: 69-73

Doi : https://doi.org/10.37547/tajssei/Volumeo3Issue08-16

younger generation in Uzbekistan FA

Mukhitdinova, SS Agzamkhodzhayeva

Eurasian Union of Scientists, 2019.

9. Problems of power and management in the works of Eastern thinkers FA Mukhitdinova, HM Mukhammedov High School, 35-38, 2015.

10. Implementation of Human rights protection in Uzbekistan IV Kudryavtsev Eurasian Union of Scientists, 2019.

11. The origins of the idea of civil society FA Mukhitdinova, IN Kudryavtsev ACTUAL ASPECTS OF MODERN SCIENCE, 102-109, 2017. 